Article - Agriculture, Agribusiness and Biotechnology

\title{
Phenotypic Characterization and Synthesis of Extracellular Catecholase from a Newly Isolated Bacterium Pseudomonas sp. BSC-6
}

\author{
Yogita Lugani ${ }^{1}$ \\ https://orcid.org/0000-0001-6152-6944 \\ Baljinder Singh Kauldhar ${ }^{2}$ \\ https://orcid.org/0000-0002-5269-7220 \\ Navneet Kaur ${ }^{1}$ \\ https://orcid.org/0000-0001-6707-1573 \\ Balwinder Singh Sooch ${ }^{1^{*}}$ \\ https://orcid.org/0000-0002-0734-539X
}

${ }^{1}$ Punjabi University, Department of Biotechnology, Enzyme Biotechnology Laboratory, Patiala, Punjab, India; ${ }^{2}$ Center of Innovative and Applied Bioprocessing, Knowledge City, Sector-81, Mohali, Punjab, India

Received: 2018.07.16; Accepted: 2019.07.08.

*Correspondence: soochb@pbi.ac.in; Tel.: +91-175-3046263 (BSS.)

\section{HIGHLIGHTS}

- A catechol degrading bacterium (BSC-6) was isolated from soil and effluent samples.

- Detailed phenotypic and genotypic characterization of the selected isolate was made.

- The characterization results reveal its close resemblance with genus Pseudomonas.

- After scale up studies, maximum catecholase activity of $152.32 \mathrm{IU} / \mathrm{L}$ was achieved.

Abstract: Catecholase (EC 1.10.3.1), an oxidoreductase enzyme is a key member of polyphenol oxidase family which catalyze the degradation of catechol. This enzyme possesses vast applications in diverse areas and is found in bacteria, fungi, mushrooms, higher plants, arthropods, amphibians and mammals. Catechol, a phenolic compound, is used as a starting material in the synthesis of various industrial compounds such as inhibitors, antioxidants, pesticides etc. The release of this phenolic compound in the environment causes toxicity to both flora and fauna. In the present studies, emphasis has been laid on isolation, screening and characterization of catechol degrading bacterium coupled with synthesis of catecholase enzyme. Further, the selected isolated strain was 
phenotypically characterized and was found to be member of genus Pseudomonas. Among all the isolates, BSC- 6 was found as best isolate with maximum extracellular catecholase activity of $152.32 \mathrm{IU} / \mathrm{L}$ obtained after scale up studies. The herein synthesized bacterial catecholase may be employed for wide applications particularly in bioremediation of phenol enriched polluted sites.

Keywords: Catecholase, Catechol, Polyphenol oxidase, Pseudomonas sp. BSC-6, Bioremediation

\section{INTRODUCTION}

Catecholase (EC 1.10.3.1), also known as Catechol oxidase or o-diphenol oxidase belongs to the class of oxidoreductases and is involved in the degradation of catechol into benzoquinone and oxygen, which are further reduced to form water [1]. It belongs to type-3 copper proteins and contains a dinuclear copper complex with histidine ligands located at the active site of enzyme [2-3]. Catecholase is commonly found in bacteria, fungi, mushrooms, higher plants, arthropods, amphibians, insects and mammals [4]. Catechol, also known as pyrocatechol or 1,2-dihydroxybenzene, is an organic phenolic compound with the molecular formula $\mathrm{C}_{6} \mathrm{H}_{4}(\mathrm{OH})_{2}$. It is an ortho isomer of the three isomeric benzenediols. Catechol is toxic by dermal and oral routes of exposure and is harmful if inhaled causing skin irritation, eye damage and is suspected to cause genetic defects. It is also reported that chronic exposure of catechol shows some levels of carcinogenicity in fishes and other aquatic organisms [5]. Phenolic compounds such as catechol is formed as an intermediate during the degradation of most of the substituted and non substituted mono and poly aromatic compounds [6]. Based on the location of hydroxyl group on carbon atoms, there are mainly two pathways for the degradation of catechol involving catecholase i.e. orthoand meta- pathway [7]. The present study was aimed at screening best catecholase producing bacterial isolate for efficient degradation of phenolic compounds. The selected bacterial isolate designated as BSC-6 was phenotypically characterized coupled with optimization of various media and process variables for maximum synthesis of extracellular catecholase. Further scales up studies at bioreactor level were conducted for the maximum production of catecholase from bacterial strain.

\section{MATERIAL AND METHODS}

\section{Collection of soil and industrial effluent samples}

Different soil and industrial effluent samples were collected from various locations of Punjab from paper and pulp, textile, pharmaceutical and dye industries during the month of March for the isolation of catecholase producing bacterial cultures. Pre-sterilized polythene bags with sterile spatula and bottles were used for the collection of soil and effluent samples. Thereafter, the collected samples were stored at $4^{\circ} \mathrm{C}$ until further use. 


\section{Enrichment and isolation of microbial strains}

The soil and effluent samples collected from various locations were added (1\%, w/v for soil samples and $1 \%, v / v$ for effluent samples each) separately in the pre-sterilized enrichment media having $\mathrm{pH} 7.0$ in separate flasks containing catechol $(1.0 \mathrm{~g} / \mathrm{L})$ and yeast extract $(2.5 \mathrm{~g} / \mathrm{L})$ to promote the growth of catechol producing bacterial strains. These flasks were incubated at $37^{\circ} \mathrm{C}$ for $24 \mathrm{~h}$. After incubation, the samples from enrichment media were streaked on the agar plates containing catechol $(1.0 \mathrm{~g} / \mathrm{L})$, yeast extract $(2.5 \mathrm{~g} / \mathrm{L})$ and agar $(20.0 \mathrm{~g} / \mathrm{L})$. These plates were further incubated at $37^{\circ} \mathrm{C}$ for $24 \mathrm{~h}$ and healthy colonies were then picked and maintained for further screening. The above streaking procedure was repeated for 3 to 4 times to get pure bacterial colonies. The pure bacterial isolates were maintained on nutrient agar slants containing peptone $(5.0 \mathrm{~g} / \mathrm{L}), \mathrm{NaCl}(5.0 \mathrm{~g} / \mathrm{L})$, beef extract $(1.50 \mathrm{~g} / \mathrm{L})$, yeast extract $(1.50 \mathrm{~g} / \mathrm{L})$ and agar $(2.0 \%, \mathrm{w} / \mathrm{v})$ with $\mathrm{pH}$ of 7.0 at $4^{\circ} \mathrm{C}$ until further use. To maintain the viability of bacterial cultures, sub-culturing of isolates was done regularly aseptically as described earlier [8].

\section{Screening of catecholase producing bacterial isolates}

The starter culture of bacterial isolates was prepared in nutrient broth medium (100 $\mathrm{mL}$ ) containing peptic digest of animal tissue $(5.0 \mathrm{~g} / \mathrm{L}), \mathrm{NaCl}(5.0 \mathrm{~g} / \mathrm{L})$, beef extract $(1.5 \mathrm{~g} / \mathrm{L})$, yeast extract $(1.5 \mathrm{~g} / \mathrm{L})$ and having $\mathrm{pH}$ 7.0. Different flasks inoculated with different bacterial isolates were incubated at $37^{\circ} \mathrm{C}$ for $24 \mathrm{~h}$ at $150 \mathrm{rpm}$. Thereafter, the fermentation media containing catechol (1.0 g/L), yeast extract $(0.4 \mathrm{~g} / \mathrm{L}), \mathrm{MgSO}_{4}(2.0 \mathrm{~g} / \mathrm{L}), \mathrm{K}_{2} \mathrm{HPO}_{4}(6.0 \mathrm{~g} / \mathrm{L})$, $\mathrm{CaCl}_{2}(0.4 \mathrm{~g} / \mathrm{L})$ and $\mathrm{NaCl}(0.5 \mathrm{~g} / \mathrm{L})$ and having a $\mathrm{pH} 7.0$ was inoculated with $5 \%(\mathrm{v} / \mathrm{v})$ inoculum. The inoculated fermentation media was incubated at $37^{\circ} \mathrm{C}$ for $36 \mathrm{~h}$ at $150 \mathrm{rpm}$. After completion of fermentation, the cell culture was centrifuged at $3000 \mathrm{~g}$ for $10 \mathrm{~min}$ at $4^{\circ} \mathrm{C}$ (5840R, Eppendorf, Germany) to separate the cell biomass. The collected cells were washed twice with the phosphate buffer $(\mathrm{pH} 7.0)$ and disrupted by sonication $(20 \mathrm{KHz}, \mathrm{VCX}$ 500 , Sonics, USA) method performed at $50 \%$ amplitude for 15 min with pulse of $15 \mathrm{sec}$ on, $15 \mathrm{sec}$ off. Both the extracellular and intracellular catecholase activity was estimated in the supernatant and enzyme extract from cell pellet [9]. One unit of enzyme is defined as amount of enzyme that decomposes one micromole of catechol per minute under standard assay conditions.

\section{Phenotypic and genotypic characterization of bacterial isolate}

The best catecholase producing bacterial isolate was identified through various morphological and biochemical characteristics [10]. The culture identification was done by observing the size, shape, texture, margin and elevation of growing bacterial colony on the surface of nutrient agar. For the morphological identification of bacterial isolate, Gram staining was performed. The biochemical characterization was done using different tests like catalase, indole production, starch hydrolysis, urea hydrolysis, gelatin hydrolysis, Methyl Red Voges-Proskauer (MRVP) and sugar fermentation (glucose, lactose, fructose, sucrose) as described in some scientific reports [11]. The selected Pseudomonas strain BSC-6, was genotypically characterized through ribosomal 16S RNA sequencing. The genomic DNA of 
the BSC-6 strain was isolated and purified using GeneiUltrapure ${ }^{\mathrm{TM}}$ Genomic DNA kit. Thereafter, a $1.2 \mathrm{~kb} 16 \mathrm{~S}$ ribosomal RNA fragment was amplified using Taq polymerase and the PCR product was then sequenced using primers. Further, the phylogenetic tree was constructed using neighbour joining method (Jukes-Cantor Model), with evolutionary analysis conducted using the MEGA6 tool.

\section{Optimization of medium constituents and process parameters}

The production of catecholase from the selected bacterial isolate was enhanced by optimizing the culture parameters like carbon source, nitrogen source, trace element and incubation time in a step wise manner. Different carbon sources like glucose, fructose, sucrose, starch, and lactose (each $1 \%, w / v)$ were supplemented in different flasks containing basal media having catechol $(1.0 \mathrm{~g} / \mathrm{L})$, yeast extract $(0.4 \mathrm{~g} / \mathrm{L}), \mathrm{MgSO}_{4}(2.0 \mathrm{~g} / \mathrm{L})$, $\mathrm{K}_{2} \mathrm{HPO}_{4}(6.0 \mathrm{~g} / \mathrm{L}), \mathrm{CaCl}_{2}(0.4 \mathrm{~g} / \mathrm{L})$ and $\mathrm{NaCl}(0.5 \mathrm{~g} / \mathrm{L})$ at $\mathrm{pH} 7.0$ to investigate their effect on production of catecholase from selected bacterial isolate BSC-6. These flasks were inoculated with $5 \%(\mathrm{v} / \mathrm{v})$ inoculum and incubated at $37^{\circ} \mathrm{C}$ for $36 \mathrm{~h}$ at $150 \mathrm{rpm}$. After incubation, the cell biomass was separated by centrifuging the cell culture at $3000 \mathrm{~g}$ for 10 min at $4^{\circ} \mathrm{C}$ and extracellular catecholase activity was estimated ${ }^{8}$. The effect of different concentrations $(1.0 \%, 1.5 \%, 2.0 \%, 2.5 \%, 3.0 \%, 3.5 \%, 4.0 \% \mathrm{w} / \mathrm{v})$ of best selected carbon source was also evaluated for catecholase production.

Different nitrogen sources namely yeast extract, malt extract, peptone, beef extract, meat extract, urea, ammonium nitrate, ammonium sulphate and potassium nitrate were supplemented in the basal medium at a concentration of $1.0 \%(\mathrm{w} / \mathrm{v})$ to study their effect on catecholase production. The effect of different concentrations $(1.0 \%, 1.5 \%, 2.0 \%, 2.5 \%$, $3.0 \%, 3.5 \%, 4.0 \% \mathrm{w} / \mathrm{v}$ ) of best nitrogen source was also studied on production of catecholase. Different trace elements like $\mathrm{FeSO}_{4}, \mathrm{MgSO}_{4}, \mathrm{KCl}, \mathrm{CaCl}_{2}, \mathrm{MnCl}_{2}, \mathrm{CoCl}_{2}, \mathrm{ZnSO}_{4}$, $\mathrm{CuCl}_{2}$ (each with $0.05 \%$ and $0.1 \%$, w/v) were also supplemented in different flasks to study their effect on catecholase production. Further, the effect of incubation time on catecholase production from selected bacterial strain BSC-6, the inoculated optimized media was incubated at $37^{\circ} \mathrm{C}$ for different time intervals. Furthermore, the effect of various process variables such as $\mathrm{pH}$ of the medium, temperature, inoculum age and size and fermentation time on catecholase production was also investigated.

\section{Fermenter studies}

Fermenter studies for bacterial production of catecholase were carried out on a laboratory scale stirred tank reactor of $1.5 \mathrm{~L}$ capacity with working volume of $1.0 \mathrm{~L}$ (Biolab, $\mathrm{B}$. Braun, Germany) having Ruston type impeller with six blades. Different parameters such as aeration $(0.25-1.25 \mathrm{vvm})$, agitation $(50-250 \mathrm{rpm})$ and fermentation time (6-60 h) were varied to achieve maximum production of catecholase enzyme. At the start of fermentation process, sterilized silicon oil $(0.005 \%$, v/v) to control foam formation was added. 


\section{RESULTS AND DISCUSSION}

\section{Isolation and screening of catecholase producing bacteria}

A total of 17 bacterial strains were isolated from the soil and effluent samples collected from various locations of Punjab. Among all the bacterial isolates, only five (05) isolates have shown positive catecholase activity and only one (01) isolate have shown catecholase activity more than $50 \mathrm{lU} / \mathrm{L}$. It has been found that amongst all the isolates, the highest extracellular catecholase activity of $52.2 \mathrm{IU} / \mathrm{L}$ was obtained from bacterial isolate designated as BSC-6. It has also been observed that most of the isolates showed extracellular catecholase activity, whereas isolates designated as BSC-11 and BSC-21 showed some intracellular catecholase activity (Table 1).

Table 1: Extracellular and intracellular catecholase activity of isolated strains.

\begin{tabular}{ccc}
\hline Microbial Isolate & $\begin{array}{c}\text { Intracellular } \\
\text { Catecholase Activity } \\
(\mathbf{I U} / \mathbf{m g} \text { of cells })\end{array}$ & $\begin{array}{c}\text { Extracellular Catecholase } \\
\text { Activity } \\
(\mathrm{IU} / \mathbf{L})\end{array}$ \\
\hline BSC-6 & Nil & $\mathbf{5 2 . 2} \pm \mathbf{2}$ \\
BSC-11 & $6.5 \pm 1$ & $18.3 \pm 2$ \\
BSC-12 & $\mathrm{Nil}$ & $13.4 \pm 4$ \\
BSC-21 & $9.2 \pm 3$ & $38.4 \pm 1$ \\
BSC-22 & $\mathrm{Nil}$ & $16.9 \pm 3$ \\
\hline
\end{tabular}

\section{Phenotypic and genotypic characterization of selected bacterial isolate BSC- 6}

The maximum catecholase producing bacterial isolate BSC-6 was identified on morphological and biochemical characteristics according to Bergey's Manual of Determinative Bacteriology [12]. The results of biochemical and morphological tests are shown in Table 2. The yellowish green colored flat colonies having smooth surface with irregular margin and irregular configuration were observed on petri plates after $24 \mathrm{~h}$ of incubation. The microscopic examination of the overnight grown BSC-6 culture was carried out after Gram staining. The presence of pink colored, rod shaped cells clearly indicated that the isolate belongs to Gram negative cells. For the further confirmation, the identification of BSC-6 isolate was carried out using biochemical characterization.

The best bacterial isolate BSC-6 showed positive tests for catalase, citrate utilization and gelatin hydrolysis, however negative results were found with indole production, starch hydrolysis and urease production, MRVP tests. The isolate showed positive results for sugar fermentation with sucrose, lactose, glucose and fructose. However, both acid and gas formation was found with glucose and lactose, whereas only acid formation was found with fructose and sucrose.

Table 2: Morphological and biochemical characteristics of BSC-6 isolate.

$\begin{array}{lccc}\text { S. No. } & \begin{array}{c}\text { Phenotypic } \\ \text { characterization }\end{array} & \text { Observation } & \text { Result }\end{array}$




$\begin{array}{lccc}\text { 1. } & \text { Gram staining } & \text { Red colored rod shaped cells } & \text { Gram -ve bacilli } \\ \text { 2. } & \text { Colony color } & \text { Yellow green } & \text { Characteristics of } \\ \text { 3. } & \text { Colony surface } & \text { Smooth } & \text { colony resemble with } \\ \text { 4. } & \text { Margin } & \text { Irregular } & \text { growth pattern of } \\ \text { 5. } & \text { Elevation } & \text { Smooth } & \text { Pseudomonas sp. }\end{array}$

\begin{tabular}{|c|c|c|c|}
\hline \multicolumn{4}{|c|}{ Biochemical tests } \\
\hline 1. & Catalase & Slight effervescence & $+v e$ \\
\hline 2. & Indole production & Formation of pink ring at surface & $-v e$ \\
\hline 3. & Citrate utilization & Blue color & + ve \\
\hline 4. & Starch hydrolysis & No clear zone & -ve \\
\hline 5. & Urease production & No color change & $-v e$ \\
\hline 6. & Methyl red & No color change & $-v e$ \\
\hline 7. & Voges proskauer & No color change & -ve \\
\hline 8. & Gelatin hydrolysis & Liquefaction & +ve \\
\hline \multicolumn{4}{|c|}{ Fermentation of sugars } \\
\hline 1. & Glucose & Red to yellow color, Gas formation & +ve \\
\hline 2. & Lactose & Red to yellow color, Gas formation & + ve \\
\hline 3. & Fructose & Red to yellow color, No gas formation & + ve \\
\hline 4. & Sucrose & Red to yellow color, No Gas formation & + ve \\
\hline
\end{tabular}

The results of morphological and biochemical tests clearly indicates that the bacterial isolate BSC- 6 belongs to genus Pseudomonas as evident by Bergey's Manual of Systematic Bacteriology and hence, the isolate was named as Pseudomonas sp. BSC-6 and was selected for further studies. The production of catecholase from several Pseudomonas sp. such as Pseudomonas putida, $P$. florescence and $P$. aeruginosa has been reported previously by various authors [13-14].

The systematic position of the isolated Pseudomonas strain BSC-6 was verified by genotypic and phenotypic tests. The present strain was placed within the genus Pseudomonas on the basis of phylogeny analysis of the $16 \mathrm{~S}$ ribosomal RNA sequence (Figure 1).

\section{Catecholase production vs growth pattern of Pseudomonas sp. BSC-6}

The growth pattern of the bacterial isolate has been presented in Figure $(2 A)$, where maximum enzyme production of $52.2 \mathrm{IU} / \mathrm{L}$ was observed after reaching stationary phase (36 h) and thereafter, decreases in enzyme activity was recorded. It can be depicted from Figure. (2A), that the catecholase production is progressively increased during log phase of growth and reaches at maximum level when microorganism reaches at stationary phase of growth. The results are also in agreement with the findings of other workers [15]. 


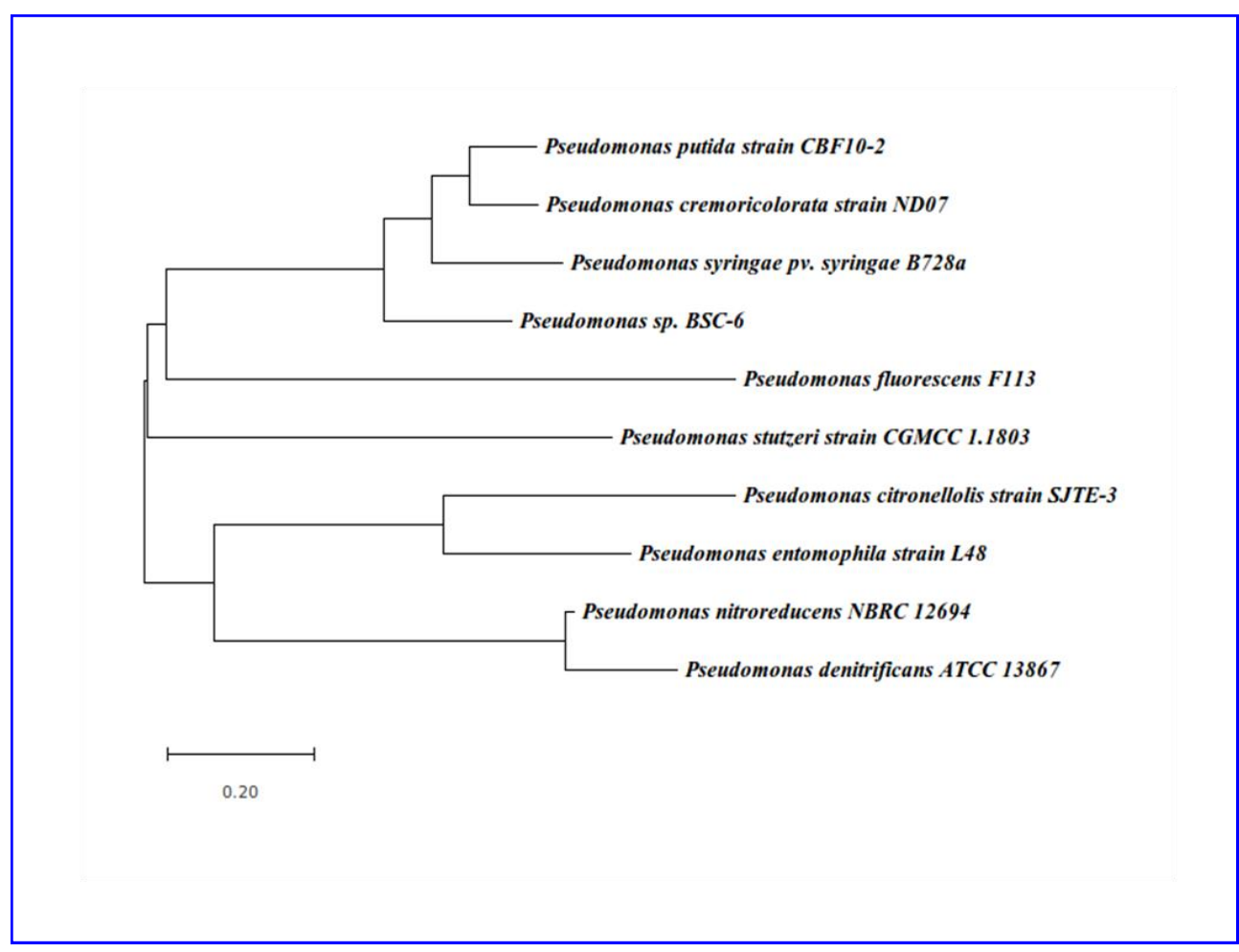

Figure 1: Neighbour joining phylogenetic tree based on $16 \mathrm{~S}$ ribosomal RNA gene sequences showing the relationship of present strain with other closely related type strains.

\section{Medium optimization studies at shake flask level for catecholase production}

The optimization of various culture parameters were performed in a step wise manner to increase the production of catecholase from selected bacterial strain BSC-6. The optimization of critical parameters such as carbon source, nitrogen source and trace element are very crucial during the development of fermentation technology to reduce the production cost of enzyme.

\section{Effect of carbon source}

Different flasks containing basal media as described in methods section was supplemented with different carbon sources $(1 \%, w / v)$ to check their effect on catecholase production. Among all the carbon sources, glucose was found to be best carbon source with maximum catecholase production of $61.4 \mathrm{IU} / \mathrm{L}$. However, minimum catecholase activity of $28.2 \mathrm{IU} / \mathrm{mL}$ was observed with sucrose. The effect of various carbon sources on catecholase production is shown in Figure (2B). To check the effect of different concentrations of carbon source on enzyme production, the best selected carbon source glucose was supplemented in different fermentation flasks in different concentrations $(1.0 \%, 1.5 \%, 2.0 \%, 2.5 \%, 3.0 \%$, $3.5 \%, 4.0 \% \mathrm{w} / \mathrm{v})$. The maximum catecholase production of $63.2 \mathrm{IU} / \mathrm{L}$ was found when glucose at a concentration of $2 \%(\mathrm{w} / \mathrm{v})$ was used as a carbon source. A progressive increase in catecholase production was observed with the increase in glucose concentration up to $2 \%$ $(\mathrm{w} / \mathrm{v})$ and thereafter, a decline in enzyme activity was observed (Figure. $2 \mathrm{C})$. The decrease in catecholase production above $2 \%(\mathrm{w} / \mathrm{v})$ may be due to inhibitory action of glucose at high concentration. It was reported previously that when Pseudomonas cultures were grown in 
basal salt medium supplemented with glucose as sole carbon source showed maximum catecholase production.

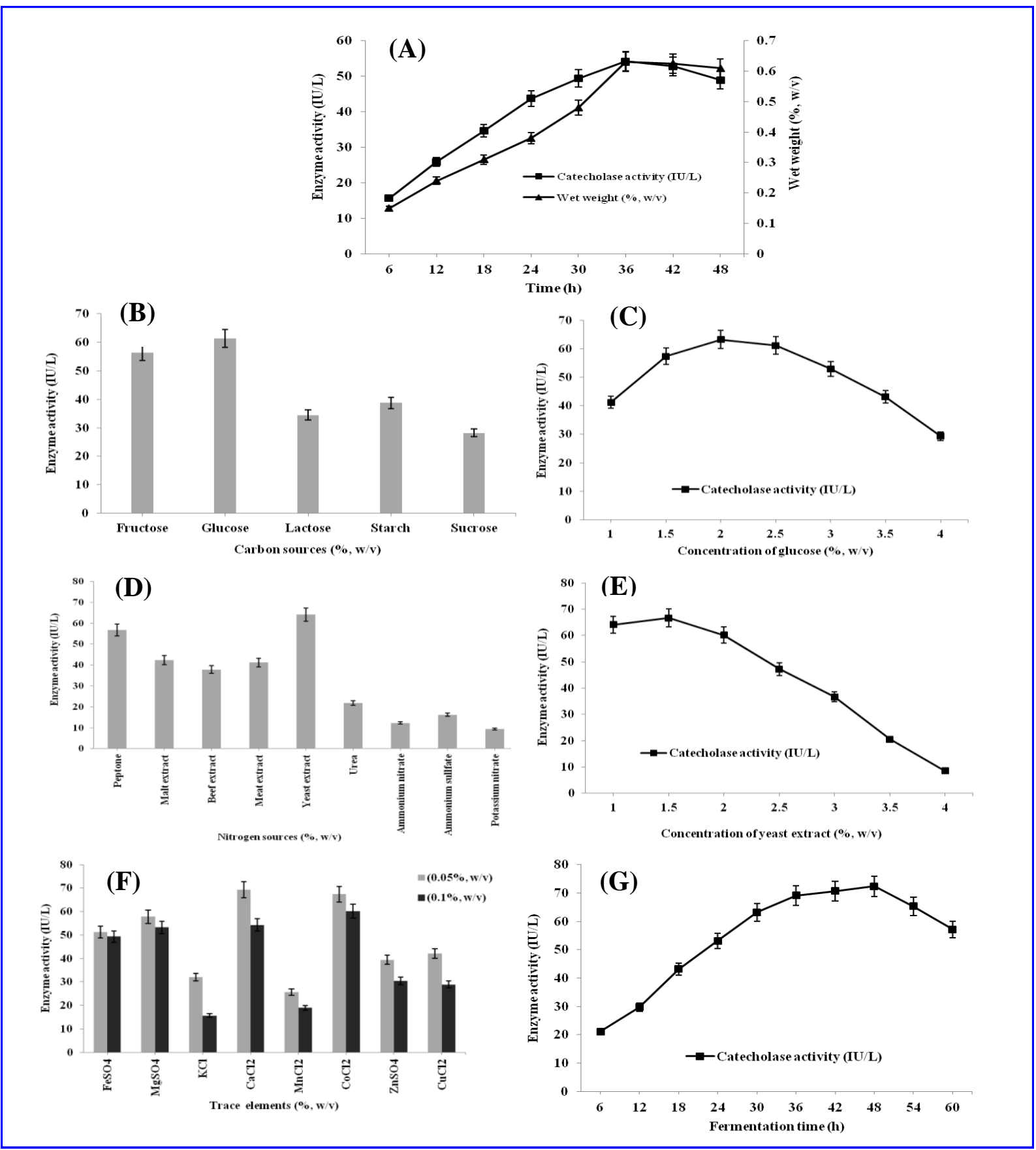

Figure 2: (a) Catecholase production vs growth pattern of Pseudomonas sp. BSC-6; effect of different medium components on catecholase production (b) carbon sources; (c) concentration of glucose; (d) nitrogen sources; (e) yeast extract; (f) trace elements; (g) incubation time.

\section{Effect of nitrogen source}

The effect of different organic and inorganic nitrogen sources like peptone, malt extract, beef extract, meat extract, yeast extract, urea, ammonium nitrate, ammonium sulphate and potassium nitrate at a concentration of $1.0 \%(\mathrm{w} / \mathrm{v})$ was observed on catecholase production after $36 \mathrm{~h}$ of incubation. Among all the nitrogen sources, the maximum catecholase 
production of $64.1 \mathrm{IU} / \mathrm{L}$ was observed by supplementing yeast extract as nitrogen source. The effect of various nitrogen sources on catecholase production is shown in Figure. (2D). The complex nitrogen sources have been found better than inorganic nitrogen sources for enzyme production. Ammonium salts usually causes acidic condition, because free acid is librated in the medium after the utilization of ammonium ions and high acidic condition may inhibit the growth and synthesis of catecholase. The preference for complex organic nitrogen sources such as yeast extract and peptone for catecholase production from various Pseudomonas sp. like $P$. fragi, $P$. fluorescens BW 96 has also been observed Olukunle and workers [16].

Further, to investigate the effect of different concentrations of nitrogen source on catecholase production, the best selected nitrogen source yeast extract was supplemented in the fermentation medium at different concentration $(1.0 \%, 1.5 \%, 2.0 \%, 2.5 \%, 3.0 \%, 3.5 \%$, $4.0 \% \mathrm{w} / \mathrm{v})$. The maximum catecholase production of $66.7 \mathrm{IU} / \mathrm{L}$ was found at a concentration of $1.5 \%(\mathrm{w} / \mathrm{v})$. The higher concentration of yeast extract was found to be inhibitory for catecholase synthesis as shown in Figure. (2E). This inhibitory action may be due to complex nature of this nitrogen source and some constituents of yeast extract may have a toxic effect on catecholase production at higher concentrations.

\section{Effect of trace elements}

The presence of trace elements in the production medium plays a vital role in the enzyme production, hence the effect of various trace elements like $\mathrm{FeSO}_{4}, \mathrm{MgSO}_{4}, \mathrm{KCl}$, $\mathrm{CaCl}_{2}, \mathrm{MnCl}_{2}, \mathrm{CoCl}_{2}, \mathrm{ZnSO}_{4}, \mathrm{CuCl}_{2}$ at different concentrations $(0.05 \%$ and $0.1 \%, \mathrm{w} / \mathrm{v})$ was examined individually on catecholase production. The improved catecholase production was found when the culture medium was supplemented with $\mathrm{CaCl}_{2}$ and $\mathrm{CoCl}_{2}$, indicating the requirement of the $\mathrm{CaCl}_{2}$ and $\mathrm{CoCl}_{2}$ for catecholase production by Pseudomonas sp. BSC-6. The maximum catecholase production of $69.3 \mathrm{IU} / \mathrm{L}$ was found with $\mathrm{CaCl}_{2}$ at a concentration of $0.05 \%(\mathrm{w} / \mathrm{v})$. The similar catecholase production of $67.4 \mathrm{IU} / \mathrm{L}$ was found when $\mathrm{CoCl}_{2}$ $(0.05 \%, \mathrm{w} / \mathrm{v})$ was added as a trace element in the fermentation media, whereas the production of catecholase was less with other trace elements as shown in Figure $2 \mathrm{~F}$.

\section{Effect of incubation time}

To investigate the effect of incubation time on enzyme production, the optimized media was incubated at different time intervals and the maximum catecholase production of 72.4 $\mathrm{IU} / \mathrm{L}$ was observed after $48 \mathrm{~h}$ of incubation as shown in Figure $2 \mathrm{G}$.

\section{Influence of process variables for catecholase synthesis}

\section{Effect of $\mathrm{pH}$ and temperature}

Figure $3 \mathrm{~A}$ and $3 \mathrm{~B}$ showed the influence of $\mathrm{pH}$ of the medium and temperature of incubation on production of catecholase enzyme, respectively. It was depicted that maximum production of catecholase was reported at $\mathrm{pH} 7.0(72.4 \mathrm{IU} / \mathrm{L})$ and thereafter with further increase in $\mathrm{pH}$ resulted in inhibition of synthesis of catecholase (Figure $3 \mathrm{~A}$ ). This decrease in enzyme synthesis with increase in $\mathrm{pH}$ may be due to change in the external $\mathrm{pH}$ 
which might have changed the ionization of nutrient molecules and thus reduced the availability to the microorganism. Further, the increase in catecholase activity was observed with the increase of temperature upto $37^{\circ} \mathrm{C}$ and thereafter it decreased (Figure 3B). The rate of enzyme synthesis in the cells increases with the increase in temperature till optimum temperature, however enzyme inactivation due to protein denaturation beyond optimum temperature affects the cell growth and productivity [17].

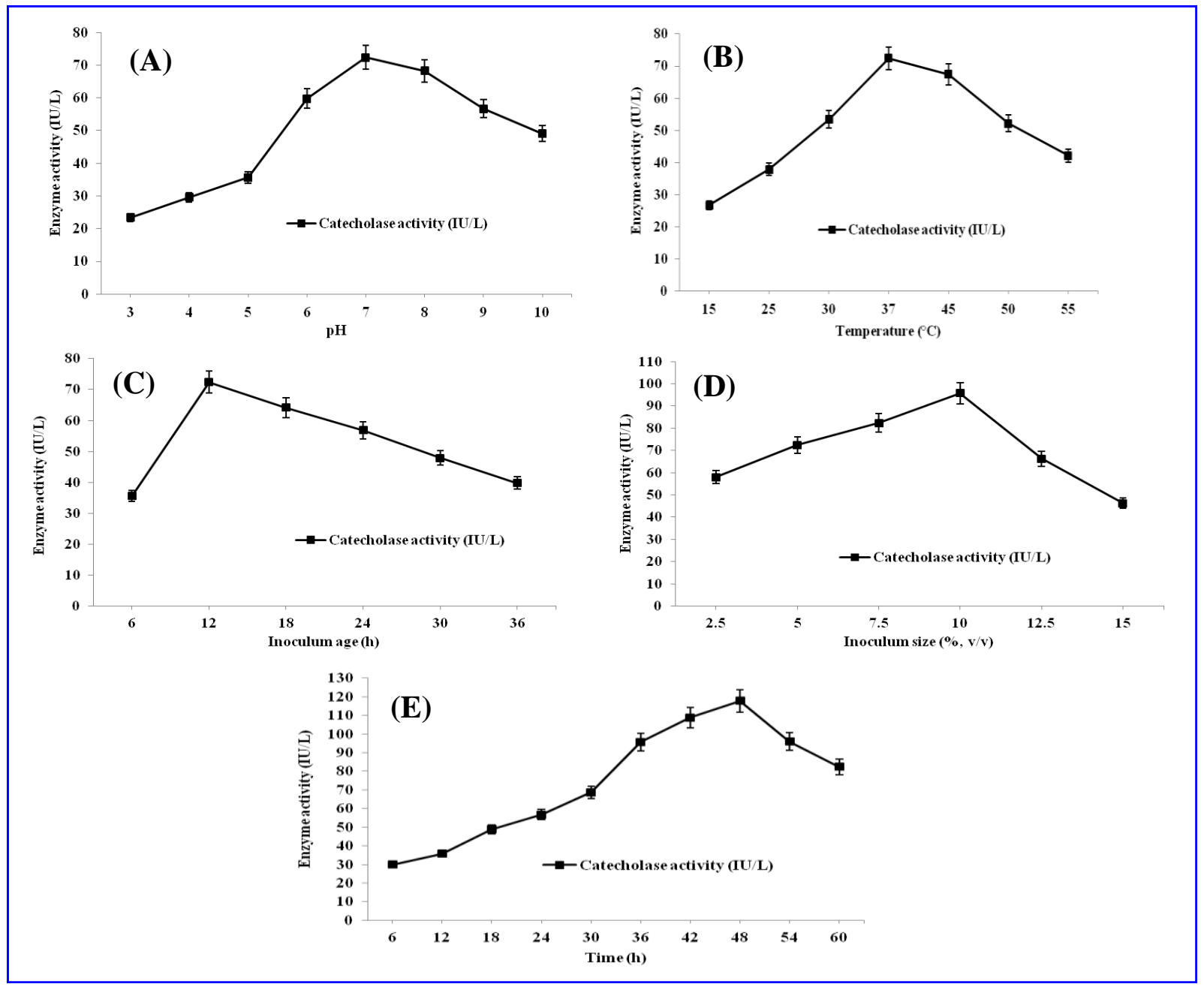

Figure 3: Effect of different process parameters on synthesis of catecholase (a) $\mathrm{pH}$; (b) temperature; (c) inoculum age; (d) inoculum size; (e) fermentation time.

\section{Effect of inoculum age and size}

Influence of culture age and size were found to be crucial parameters that exert a significant effect on the synthesis of catecholase production. The synthesis of catecholase from Pseudomonas sp. BSC-6 using $12 \mathrm{~h}$ old inoculum was recorded to be $72.4 \mathrm{IU} / \mathrm{L}$ (Figure $3 \mathrm{C}$ ), whereas a low catecholase activity was obtained by using cells of inoculum age below $12 \mathrm{~h}$, which could be due to the fact that bacterial cells might not have reached the exponential growth phase at that time. Further, an increase in synthesis of bacterial catecholase $(95.7 \mathrm{IU} / \mathrm{L})$ was also recorded with the increase in inoculum size up to $10.0 \%$ $(\mathrm{v} / \mathrm{v})$, and thereafter, it decreased which may be due to nutritional imbalance due to stiff 
competition for nutrients between the cells at higher inoculum size (Figure 3D). This ultimately leads to a decrease in the synthesis of catecholase production.

\section{Effect of fermentation time}

As depicted from Figure (3E), an increase in catecholase synthesis upto $48 \mathrm{~h}$ of incubation was observed (95.7 IU/L) and thereafter, enzyme production decreased. This decline in enzyme synthesis after $48 \mathrm{~h}$ of fermentation could be due catabolite repression of enzyme or due to decline in nutrient availability in the medium.

\section{Scale Up Studies/ Fermenter Studies}

A considerable increase in synthesis of bacterial catecholase (152.3 IU/L) was observed during scale up as compared to enzyme production at shake flask level, when all the parameters optimized at flask level were used in the fermenter studies. As evident from Figure (4A), it was observed that an increase in catecholase production (117.8 IU/L) on increasing the agitation rate up to $150 \mathrm{rpm}$ was investigated and thereafter, a decrease in enzyme production was recorded.

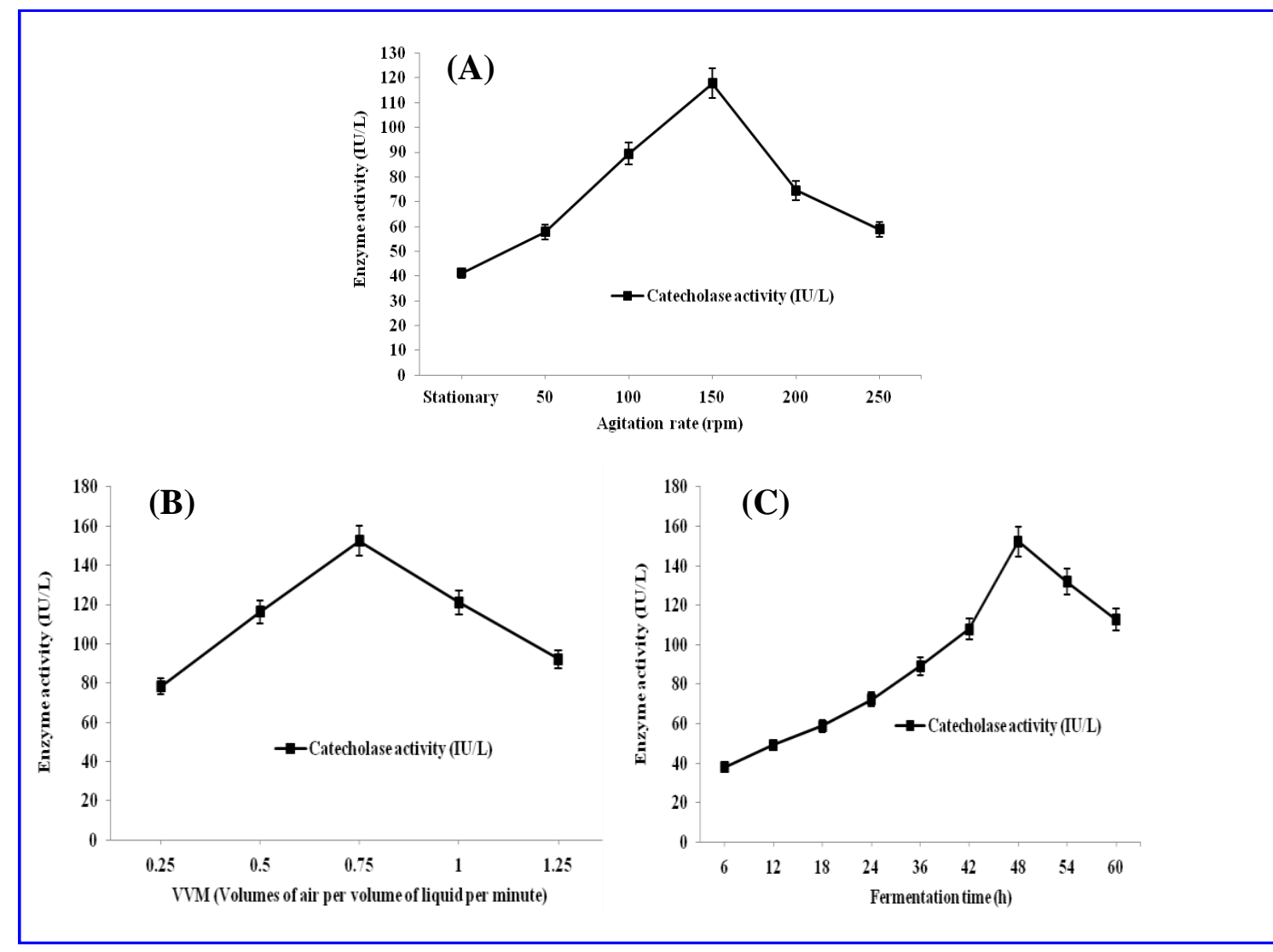

Figure 4: Effect of bioreactor parameters on extracellular synthesis of catecholase (a) agitation rate; (b) aeration rate; (c) fermentation time.

This decrease in production of catecholase may have occurred due to shear stress on bacterial cells and on enzyme structure at higher agitation rates. Further, an increase in synthesis of enzyme (152.3 IU/L) was also observed with the increase in aeration rate up to $0.75 \mathrm{vvm}$ and thereafter, a decline at higher aeration rate was observed (Figure 4B). The 
higher catecholase production could be due to the adequate oxygen transfer between cells during fermentation processes. Furthermore, the effect of fermentation time on enzyme synthesis was also studied at $6 \mathrm{~h}$ intervals upto $60 \mathrm{~h}$ of incubation. It was observed that catecholase synthesis initiated after $6 \mathrm{~h}$ of incubation and maximum enzyme production of $152.3 \mathrm{IU} / \mathrm{L}$ was observed after $48 \mathrm{~h}$ of fermentation (Figure $4 \mathrm{C}$ ). The increase in catecholase synthesis could be attributed to continuous oxygen transfer and homogeneous nutrient supply in fermenter which might have affected the physiology of Pseudomonas sp. BSC-6 cells by meeting their metabolic requirements.

\section{CONCLUSIONS}

Pseudomonas sp. BSC-6 isolated from effluent sample was found to be potent producer of catecholase enzyme. Under the optimal conditions, a 2.91 fold increase in synthesis of catecholase enzyme was recorded during scale up studies. The herein synthesized bacterial catecholase could be a prospective solution for the bioremediation of phenol enriched polluted sites.

Acknowledgements: The authors thank Department of Biotechnology, Punjabi University, Patiala, India for providing necessary facilities.

Conflicts Of Interest: The authors declare that they have no conflict of interest.

\section{REFERENCES}

1. Panadare D, Rathod VK. Extraction and purification of polyphenol oxidase: A review. Biocatal Agri Biotechnol. 2018 April;14:431-437.

2. Mishra BB, Gautam S. Polyphonel Oxidases: Biochemical and molecular characterization, distribution, role and its control. Enzy Eng. 2016 Feb;5:1-9.

3. Guell M, Siegbahn PE. Theoretical study of the catalytic mechanism of catechol oxidase. J Biol Inorg Chem. 2007 Nov;12(8):1251-1264.

4. Diwakar SK, Naik G, Mishra SK. Polyphenol oxidase enzyme: A review. In: Dwivedi AK, editor. Transdisciplinary Environmental Issues. Germany: Lap Lambert Academic Publishing; 2015. p.39-88.

5. Kamal A, Gasmalla MA, Alyousef H. Efficient methods for polyphenol oxidase production. Int J Nutr Food Sci. 2015 Nov;4:656-659.

6. Begona PM, Hidalgo A, Serra JL, Llama MJ. Degradation of phenol by Rhodococcus erythropolis UPV-1 immobilized on biolite in a packed-bed reactor. J Biotechnol. 2002 July;97(1):1-11.

7. Fialova A, Boschkeb E, Bleyb T. Rapid monitoring of the biodegradation of phenol-like compounds by the yeast Candida maltosa using BOD measurements. Int Biodet Biodeg. 2004 July;2:54-69.

8. Sooch BS, Kauldhar, BS. Influence of multiple bioprocess parameters on production of lipase from Pseudomonas sp. BWS-5. Braz Arch Biol Technol. 2013 Sept/Oct;56(5):711-721.

9. El-Bayoumi MA, Frieden E. A spectrophotometric method for the determination of the catecholase activity of tyrosinase and some of its applications. J Am Chem Soc. 1957 Sept;79(18):4854-4858.

10. Janiyani KL, Hate SR, Joshi SR. Morphological and biochemical characteristics of bacterial isolates degrading crude oil. J Env Sci Health Part A: Env Sci Eng Toxicol. 1993 Dec;28(6):1185-1204. 
11. Zahoor S, Javed, HM, Babar ME. Characterization of a novel hydrolytic enzyme producing thermophilic bacterium isolated from the hot spring of azad kashmir-Pakistan. Braz Arch Biol Technol. 2016 July;59:1-13.

12. Sneath PHA, Mair NS, Sharpe ME, Holt JG. Bergey's manual of systematic bacteriology. 1st ed. Vol. 2. London: Williams and Wilkins; 1986. 630p.

13. Diaz E, Prieto MA, Sherman D. Bacterial promoters triggering biodegradation of aromatic pollutants. Curr Opin Biotech. 2000 Oct;11:467-475.

14. Zeyaullah MD, Abdelkafe AS, Zabya WB, Arif A. Biodegradation of catechols by micro-organisms - A short review. Afr J Biotechnol. 2009 July;8:2916-2922.

15. Jukanti AK, Bruckner PL, Fischer AM. Molecular and biochemical characterization of polyphenol oxidases in developing kernels and leaves of wheat (Triticum aesticum). Fun Plant Biol. 2006 Jan;33:685-696.

16. Olukunle OF, Babajide O, Boboye B. Effects of temperature and $\mathrm{pH}$ on the activities of catechol 2,3- dioxygenase obtained from crude oil contaminated soil in Ilaje, Ondo State, Nigeria. Open Microbiol J. 2015 July;9:84-90.

17. Sahu GK, Martin, M. Optimization of growth conditions for the production of extracellular lipase by bacterial strains from dairy industry effluents. Biotechnol Bioinf Bioeng. 2011;1(3):305-311. 